Composites Research, 26(1), 7-13(2013), pISSN: 1598-6934

DOI: http://dx.doi.org/10.7234/kscm.2013.26.1.7

논문

강/복합재 이중구조 실린더 설계를 위한 유한요소 해석

김태환 ${ }^{*}$, 김위대 $^{*+}$, 정철곤 ${ }^{* *}$

\title{
Finite Element Analysis for the Design of Fiber Reinforced Metal Cylinder
}

\author{
Tae-Hwan Kim*, Wie-Dae Kim ${ }^{*+}$, Chul-Gon Jeong ${ }^{* *}$
}

\begin{abstract}
This paper describes the design of dual-structured and thick-walled cylinder made of composites and special steel. The structure of special steel and composites reduce the weight of a product maintaining its property which is proper to the characteristics. Hence they are used in the fields, such as various ground weapons, aerospace and sports industries, where high elasticity and low weight are required. Thus in this study, the analysis was conducted to find the most proper composite application method changing its types and angle of laminates for the design. Through the comparison of the results, we suggest the method for composite application which is the most appropriate to the designing purpose of this study.
\end{abstract}

\section{초 록}

본 연구에서는 특수강과 복합재료를 사용한 이중구조 실린더의 설계를 위한 해석에 대해서 기술하였다. 특수강과 복합재의 이중구조는 제품의 특성에 적합한 물성을 유지하면서도 무게를 절감해 줄 수 있으며, 이로 인해 고탄성 저중량을 필요로 하 는 각종 지상무기 산업분야와 항공분야, 스포츠 관련 분야 등에 점차 확대. 적용되고 있다. 따라서 본 연구에서는 하나의 설 계에 복합재의 적층각, 종류 등을 바꾸어 가며 이중구조의 설계에 가장 적합한 복합재 적용 방법을 찾기 위해 해석을 실시하 였다. 또한 해석의 결과 값들의 비교를 통해 본 연구 설계목표에 가장 알맞은 복합재 적용 방법을 제시하였다.

Key Words : 강/복합재 이중구조 후육 실린더(fiber reinforced metal cylinder), 복합재료(composite materials), 자긴 효과 (autofrettage effect)

\section{1. 서 론}

지상 무기 분야와 스포츠 분야, 항공 분야 등 여러 분야에 서 높은 강도를 유지하면서 구조적 설계를 통한 이상적인 무 게 절감은 한계에 다다르고 있다. 이에 대응하여 새로운 대안 으로 떠오르는 것이 재료 개발에 따른 무게절감인데, 그 재료 중 하나가 복합재료 사용이다. 현재 개발되어 있는 복합재료 중에서도 특수강을 충분히 대체할 수 있는 물성을 가지고 있
는 재료들이 몇 가지 있다. 복합재료를 사용하여 특수강의 일 부분을 대체하여 무게절감의 이득을 얻을 수 있는 실린더의 설계 요소 설정을 제시하였다. 설계에 중요한 요소로는 복합 재의 종류, 적층각, 자긴 가공 등이 있다. 자긴 가공과 관련 하여 자긴 가공의 횟수를 달리하여 연구를 실시하여 바우싱 거 효과에 대해 비교하였다[1]. 또한 자긴 가공을 할 경우. Von-Mises stress 값이 가장 낮게 나오는 자긴 압력을 구하고 이론식과 유한요소 해석에서 구해진 응력 값을 비교한 연구

\footnotetext{
접수: 2012년 9월 21일, 수정: 2013년 1월 09일, 게재승인: 2013년 1월 15일

* 부산대학교 항공우주공학과 항공우주공학전공 대학원

*+ 부산대학교 항공우주공학과, Corresponding author(E-mail:wdkim@pusan.ac.kr)

** 현대위아 주식회사
} 
가 있었다[2]. 2007-2009년에 자긴 가공 후 잔류응력과 기계 가공에 대한 연구를 시행하였다[3-4]. 자긴 가공과 자긴 후 내압에 대한 응력해석에 관해 이론식과 유한요소 해석을 통 한 응력 값의 비교를 통해 제시하였다[5]. 또 하나의 요소인 적층각과 관련하여서는 2006년에 연구를 시행하여 결과를 제 시하였다[6]. 그리고 2004년 열탄성 응력해석에 관련하여 연 구가 있었다[7]. 이를 기반으로 하여 내압해석에 필요한 유한 요소 해석 이론식[8-9]와 2010년도에 연구한 유한요소 프로그 램을 사용한 열 구조 해석 연구[10]를 바탕으로 연구를 실시 하였다. 또한 2012년에 복합재료 식을 사용하여 LabVIEW를 기반으로 한 GUI 프로그램 개발[11]을 하여 Nastran\&Patran 프로그램의 해석결과와 비교한 것을 참고하였다.

본 연구에서는 이중구조 실린더에 적합한 재료 선정과 적층 각의 배합, 그리고 앞서 연구한 자긴 효과 적용에 이어 온도효 과를 추가적으로 고려한 유한요소 해석을 실시하여 각 효과의 필요성에 대해 제시하였다. 설계의 검증을 위해 유한요소해석 프로그램인 Patran, Nastran, Abaqus를 사용하여 2D 해석을 수 행하였고, 해석의 검증을 위해 CDS 프로그램을 사용하여 결과 를 비교하였다. 적층각의 배합과 재료 선정에 있어서는 하중조 건에 내압만을 작용한 $2 \mathrm{D}$ 해석을 실시하였고, 해석의 응력 결 과 값을 비교하여 이중구조 실린더의 설계에 가장 적합한 적 층각과 재료를 도출하여 자긴 효과와 온도 효과를 고려한 해 석을 실시하였다. 자긴 효과의 연구에 대해서는 앞서 연구되었 던 자료를 참고하여 유한요소 해석을 통한 자긴 효과의 잔류 응력 적용의 정확도를 이론값과 비교하여 확인하였다. 또한 검 증이 끝난 자긴 효과에 온도효과를 추가적으로 고려하여 해석 을 실시하였으며, 그 응력 결과 값을 통해 온도효과의 영향성 에 대해 제시함으로써, 내압을 받는 자긴 가공된 금속재에 복 합재료를 적용한 실린더 설계의 기초를 마련하였다.

\section{2. 유한요소해석}

\section{1 이중구조의 내압 해석}

일반적으로 구조적 힘이 작용하지 않고, 외부압력이 없이 내부압력만 있는 실린더에 사용되는 응력 식은 다음과 같다.

$$
\begin{gathered}
\sigma_{r}=\frac{p_{i} r_{i}^{2}}{r_{o}^{2}-r_{i}^{2}}\left(1-\frac{r_{o}^{2}}{r^{2}}\right) \\
\sigma_{\theta}=\frac{p_{i} r_{i}^{2}}{r_{o}^{2}-r_{i}^{2}}\left(1+\frac{r_{o}^{2}}{r^{2}}\right)
\end{gathered}
$$

여기에서 $\sigma_{r}, \sigma_{\theta}$ 는 각각 반경방향과 원주방향의 응력을 나타내며, $p_{i}$ 는 내부응력, $r_{i}, r_{0}$ 는 각각 실린더의 내경과 외경을 나타낸다(Fig. 1).

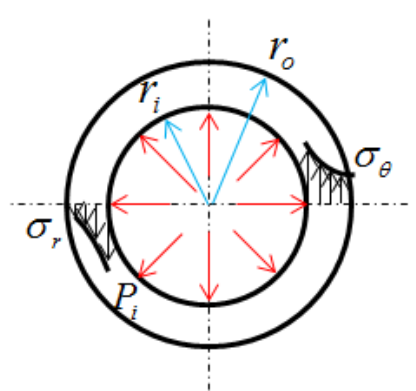

Fig. 1 실린더에서 내압만 작용할 때의 응력 선도.

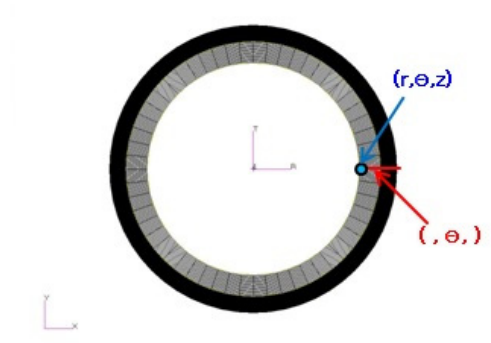

Fig. 2 해석을 위한 유한요소 모델.

또한 응력-변형률에 관한 식은 다음과 같다.

$$
\left\{\begin{array}{c}
\sigma_{z} \\
\sigma_{\theta} \\
\sigma_{r} \\
\tau_{\theta r} \\
\tau_{z r} \\
\tau_{z \theta}
\end{array}\right\}=\left[\begin{array}{cccccc}
C_{11} & C_{12} & C_{13} & 0 & 0 & C_{16} \\
C_{12} & C_{22} & C_{23} & 0 & 0 & C_{26} \\
C_{13} & C_{23} & C_{33} & 0 & 0 & C_{36} \\
0 & 0 & 0 & C_{44} & C_{45} & 0 \\
0 & 0 & 0 & C_{45} & C_{55} & 0 \\
C_{16} & C_{26} & C_{36} & 0 & 0 & C_{66}
\end{array}\right]\left\{\begin{array}{c}
\epsilon_{z}-\alpha_{z} \Delta T \\
\epsilon_{\theta}-\alpha_{\theta} \Delta T \\
\epsilon_{r}-\alpha_{r} \Delta T \\
\gamma_{\theta r} \\
\gamma_{z r} \\
\gamma_{z \theta}-\alpha_{z \theta} \Delta T
\end{array}\right\}
$$

상용프로그램인 Nastran에서의 해석을 위한 강/복합재 이 중구조 설계에 사용된 유한요소 모델을 Fig. 2에 나타내었다. 요소로는 2D shell QUAD4 요소를 사용하였으며, 강재와 복 합재 각각 720,15552 개의 요소를 사용하였다. 강재부분에는 AISI 4340을 사용하였고, 자긴 가공과 winding tension, 온도 조건을 배제하여 내압만을 작용하여 해석을 실시하였다. 또 한 복합재 부분에는 강부와 동일 요소를 사용하였으며, T300/5208, IM7/8552, T800/924C 등의 여러 재료를 적용하 였으며, 재료들의 물성 값은 Table 1,2 에 제시하였다.

Table 1 AISI 4340 의 기계적 물성

\begin{tabular}{c|c}
\hline \hline Value & Property \\
\hline $\mathrm{E}(\mathrm{psi})$ & $29.7 \times 10^{6}(\mathrm{psi})$ \\
$\nu$ & 0.29 \\
$\mathrm{G}(\mathrm{psi})$ & $11.51 \times 10^{6}(\mathrm{psi})$ \\
$E_{y}(\mathrm{psi})$ & $1.71 \times 10^{5}(\mathrm{psi})$ \\
\hline \hline
\end{tabular}




\begin{tabular}{|c|c|c|c|}
\hline & Т300/5208 & IM7/8552 & T800/924C \\
\hline$E_{11}(\mathrm{psi})$ & $26.25 \times 10^{6}$ & $20.25 \times 10^{6}$ & $26.25 \times 10^{6}$ \\
\hline$E_{22}(\mathrm{psi})$ & $1.49 \times 10^{6}$ & $1.65 \times 10^{6}$ & $26.25 \times 10^{6}$ \\
\hline$E_{33}(\mathrm{psi})$ & $1.49 \times 10^{6}$ & $1.65 \times 10^{6}$ & $26.25 \times 10^{6}$ \\
\hline$\nu_{12}$ & 0.28 & 0.32 & 0.35 \\
\hline$\nu_{13}$ & 0.28 & 0.32 & 0.35 \\
\hline$\nu_{23}$ & 0.43 & 0.46 & 0.23 \\
\hline$G_{12}(\mathrm{psi})$ & $10.40 \times 10^{5}$ & $6.89 \times 10^{5}$ & $8.70 \times 10^{5}$ \\
\hline$G_{13}(\mathrm{psi})$ & $10.40 \times 10^{5}$ & $6.89 \times 10^{5}$ & $8.70 \times 10^{5}$ \\
\hline$G_{23}(\mathrm{psi})$ & $7.29 \times 10^{5}$ & $5.65 \times 10^{5}$ & $8.56 \times 10^{5}$ \\
\hline
\end{tabular}

하중조건은 Table 3에 나타나 있다. 자긴 효과와 온도 효과 를 배제하고, 내압만을 작용시켜 첫 단계 해석을 수행하였다.

Table 3 재료 선정에 사용된 하중조건

\begin{tabular}{c|c}
\hline \hline Value & Property \\
\hline$P_{i}$ & $43,000(\mathrm{psi})$ \\
$P_{o}$ & 0 \\
\hline \hline
\end{tabular}

강부를 각각 외부에서 반경기준으로 $3 \%, 5 \%$ 의 외경 부위를 제거한 뒤 복합재료로 대체하였을 경우 동일 내압에 대해 해 석을 실시하여 원주 방향의 응력(Hoop stress) 결과 값을 비교 하였다. 이는 내압실린더의 경우 Hoop stress가 가장 취약하기 때문이다. 기준은 강부의 외벽을 제거하지 않은 기존의 강으 로만 이루어진 실린더를 Table 3에 제시된 내압을 사용하여 해석 후 원주 방향 응력 기준 값으로 정하였다. Table 4에 각 각의 경우에 최대 원주 방향 응력 값을 기준으로 기존 실린더 를 기준으로 원주 방향 응력 값을 비교하여 백분율로 나타내 었으며 비교 값이 $100 \%$ 가까울수록 기존 단일강 실린더에 걸 리는 내압을 견딜 수 있는 대체 복합재료로 알맞은 재료라고 생각할 수 있다. 적층 수는 모두 72 층이며, $\mathrm{A}$ 는 $90^{\circ}, 0^{\circ}, 54.75^{\circ}$ 를 섞어서 적층한 것이고, $\mathrm{B}$ 는 $90^{\circ}, \mathrm{C}$ 는 $0^{\circ}$ 만을 적층하여 해 석한 것이다. 여기에서 $90^{\circ}$ 는 Hoop방향을 의미한다.

Table 4 기존의 실린더와의 동일한 내압에 의한 응력 비

\begin{tabular}{|c|c|c|c|c|}
\hline \multicolumn{2}{|c|}{} & \multicolumn{2}{|c|}{ 대체된 강재의 비율 } \\
\cline { 3 - 5 } & \multirow{3}{*}{$\mathrm{T} 300 / 5208$} & $5 \%$ & $3 \%$ \\
\hline & & $\mathrm{A}$ & 71.6 & 80.2 \\
\cline { 3 - 5 } & $\mathrm{B}$ & 87.0 & 94.9 \\
\hline & \multirow{3}{*}{ 복합재 } & $\mathrm{C}$ & 59.3 & 69.1 \\
\cline { 3 - 5 } & \multirow{3}{*}{$\mathrm{T} 800 / 924 \mathrm{C}$} & $\mathrm{A}$ & 70.0 & 79.3 \\
\cline { 3 - 5 } & & $\mathrm{B}$ & 84.9 & 97.0 \\
\cline { 3 - 5 } & & $\mathrm{C}$ & 59.3 & 68.8 \\
\cline { 3 - 5 } & \multirow{3}{*}{$\mathrm{IM}$} & $\mathrm{A}$ & 69.3 & 78.1 \\
\cline { 3 - 5 } & & $\mathrm{B}$ & 83.0 & 90.9 \\
\hline & & $\mathrm{C}$ & 59.3 & 68.8 \\
\hline
\end{tabular}

*적층각 - A: $90^{\circ}, 0^{\circ}, 54.75^{\circ} \quad$ B: $90^{\circ} \quad$ C: $0^{\circ}$

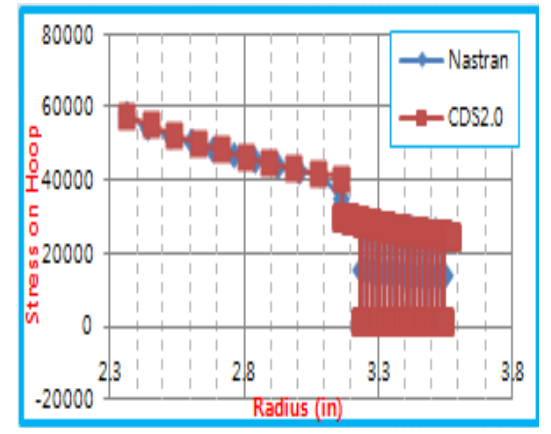

Fig. 3 동일한 하중조건에 의한 원주방향 응력 비교.

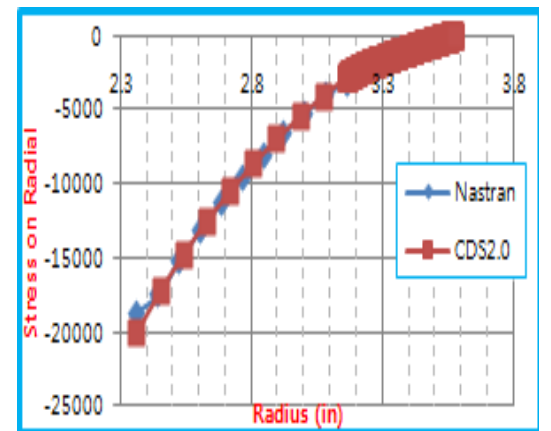

Fig. 4 동일한 하중조건에 의한 반경방향 응력 비교.

이러한 해석 결과를 보면 다른 복합재에 비해 T300/5208 이 상대적으로 우수한 재료임을 알 수 있고, $\mathrm{B}$ 적층, 즉 $90^{\circ}$ 적층이 가장 유리함을 알 수 있다. 그러나 축방향이나 반경 방향의 안전성을 고려하면 $\mathrm{A}$ 적층과 같이 여러 각도가 섞이 는 것이 바람직하고 현실성이 있다고 판단된다.

따라서 두 번째 단계로 선정된 재료를 기준으로 본 연구의 목표인 이중구조 실린더 설계에 알맞은 적층각을 찾는 해석을 실시하였다. 해석에는 $\mathrm{CDS}$ 프로그램을 사용하였으며 요소의 설정이 각층마다 10 개의 요소로 이루어져 있다. 또한 Nastran 과의 비교,검증을 실시하였다. 두 프로그램의 신뢰성과 결과의 타당성을 검증하기 위해 A적층 20000psi의 내압이 작용하는 2D 실린더 해석을 실시하여 Fig. 3-4에 나타내었다.

비교 결과 두 가지 잘 일치하는 경향을 보이고 있는데, 복합재 부분에서 원주방향응력에서 차이를 보이고 있다. 확 인 결과 이는 $\mathrm{CDS}$ 프로그램의 한계이며, NASTRAN의 반경 방향의 요소수를 약 3배정도 증가시키면 본 결과로 수렴함을 확인하였다. 따라서 이후에는 NASTRAN 모델링으로 해석을 수행하였다.

모델의 타당성 검증 후 동일한 조건 내에서 $0 \sim 90^{\circ}$ 사이의 적 층각들을 타 논문들에서 제시된 값들을 토대로 임의로 적층한 후 해석을 실시하여 응력 값을 비교해 본 결과, 다음의 세가지 적층으로 압축하여 72-75층의 복합재 해석 결과를 비교하였다. 


\section{B : $[90 /+-54.75]_{12}[90 /+-54.75 / 0]_{9}$ \\ D : $[90]_{4}[+-85]_{4}[+-80]_{4}[+-75]_{4}[+-70]_{4}[+-65]_{4}[+-60]_{4}$ $[+-55]_{4}[+-50]_{4}[+-45]_{2}$ \\ $\mathrm{T}:[90]_{10}[90 / 90 / 90 / 0]_{15}[0]_{5}$}

Fig. 5-7은 각각 축방향, 원주방향, 반경방향에 대해 안전 계수(Factor of safety)를 표시 했는데 세가지 적층 모두 응력 안전계수가 ' 1 '이상의 값을 만족하였다. B,T의 경우는 응력 분포가 급격하게 변하여 실용성에 문제가 발생할 가능성이 있는 것으로 보여져 $\mathrm{D}$ 적층처럼 점진적 적층각 변화가 바람 직한 것으로 나타났다. 물론 이 경우 실제 제작 시에는 제작 시간과 비용이 증가할 가능성이 있다.

복합재의 경우 안전계수만으로는 파괴의 판단지표로 사용 되기 어렵기 때문에 Tsai-Wu failure index를 사용하여 Fig. 8 에 표시하였다. 이 지표가 ' 1 ' 보다 크면 파괴를 의미하는 데 $\mathrm{T}$ 적층각의 경우 ' 1 '이상의 값을 가져 파괴가 되는 것으 로 나타났고, $\mathrm{B}$ 와 $\mathrm{D}$ 의 적층각이 안전한 것으로 나타났다. 그 러나 B적층각의 경우는 급격한 계단모양이 생겨 응력의 변 화가 급격하므로 장시간 사용 시 문제를 일으킬 가능성이 높 은 반면, $\mathrm{D}$ 적층각의 경우는 완만한 형상을 하고 있어 안전 에 유리하다고 판단된다.

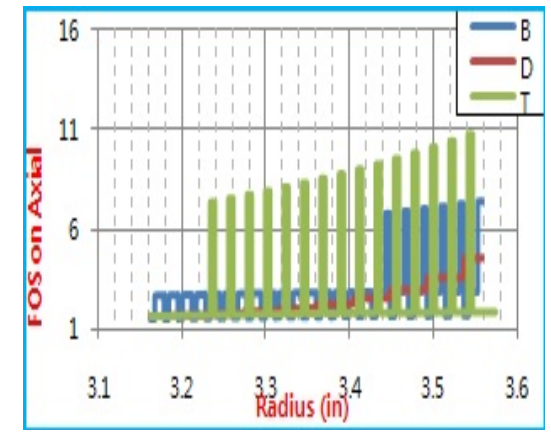

Fig. 5 복합재에서의 축 방향 응력 안전계수.

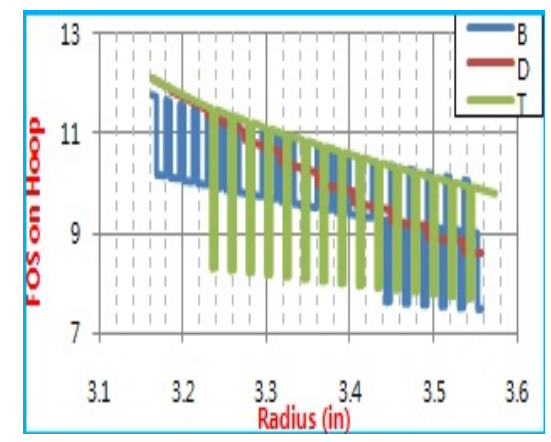

Fig. 6 복합재에서의 원주 방향 응력 안전계수.

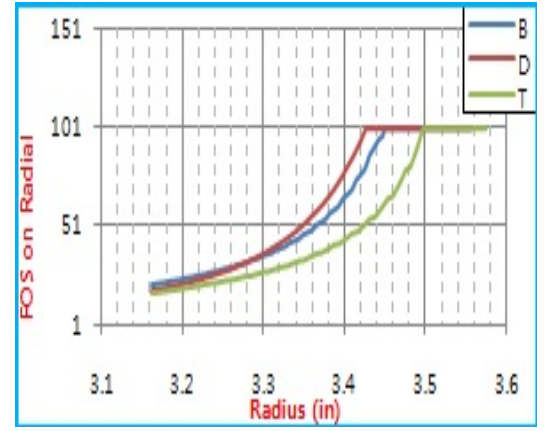

Fig. 7 복합재에서의 반경 방향 응력 안전계수.

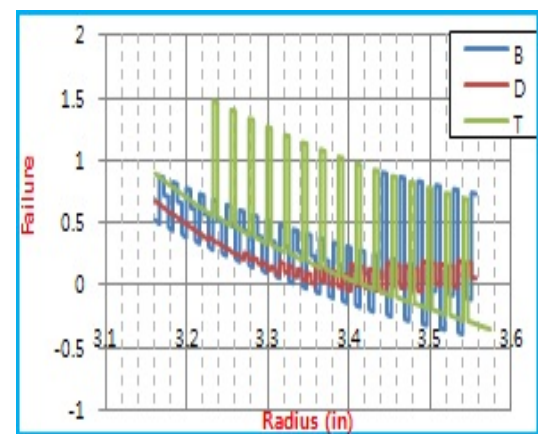

Fig. 8 Curves of Tsai-Wu values on each stacking sequence.

\section{2 자긴 가공 해석}

자긴 가공은 강부에 일정 압력을 가한 후 제거하여 내경 부터 원하는 반경까지의 잔류응력을 유도하는 것으로 항복응 력을 더 높게 하여 탄성 영역확대로 인한 소성변화를 방지하 는 것으로 대표적인 방법으로는 유압식과 스웨이징 방식이 있다. 계산에 사용되는 식은 타 논문을 참고하였다.[5]

Fig. 9는 Nastran 프로그램의 자긴 효과를 고려한 2D 정 해석에 사용된 모델이며, QUAD4 요소를 사용하였으며 요소 의 수는 60 개로 설정하였다. Nastran과 Abaqus에서 각각 동 일 모델을 사용하였다.

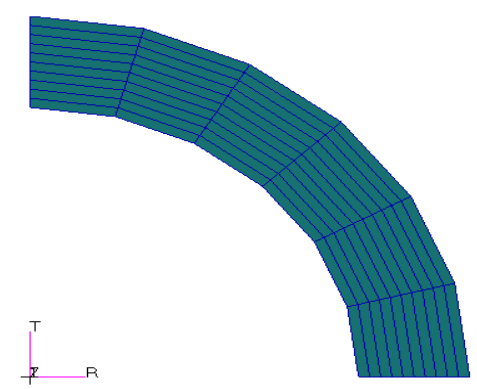

Fig. 9 2D 자긴 가공 해석을 위한 설계. 
유한요소 프로그램을 사용한 자긴 가공 해석의 검증을 위해 Nastran 2D 해석의 원주방향 응력 결과와 Abaqus 프로그램을 사용한 원주방향 응력 결과 값, Von-Mises 이론식을 사용하여 도출한 원주방향 응력의 결과 값을 비교한 그래프를 Fig. 10에 나타내었고 그 하중조건은 Table 5에 제시하였다. 그래프에 나 타나듯이 3개의 해석 결과 모두 Von-mises의 이론식과의 원주 방향 응력 값의 차이가 약 $5 \%$ 이내에 드는 것을 볼 수 있다. 이로써 자긴 가공의 효과를 Nastran과 Abaqus에서 정확히 구현 하여 본 연구의 목적에 응용할 수 있는 것을 검증하였다.

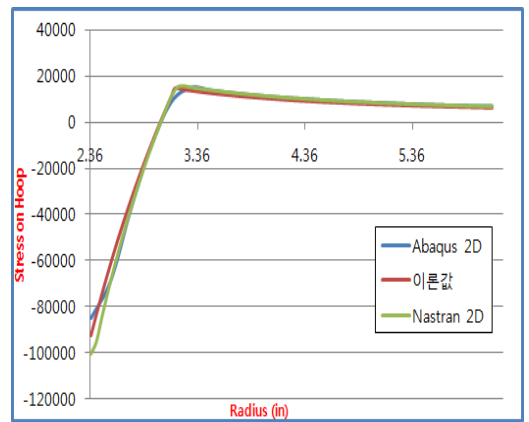

Fig. $1021 \%$ 자긴 가공 후 원주방향 잔류응력.

Table 5 자긴 가공에 사용된 하중조건

\begin{tabular}{c|c}
\hline \hline Value & Property \\
\hline$P_{i}$ & $129,000(\mathrm{psi})$ \\
$P_{o}$ & 0 \\
\hline \hline
\end{tabular}

자긴 가공 후 잔류응력으로 인한 자긴 효과가 존재하는 경우 내압이 작용하는 해석의 신뢰성을 알아보기 위해 Abaqus 프로그 램을 통해 2D 해석을 실시하고 CDS 프로그램과 원주 방향 응력 을 비교한 그래프가 Fig. 11에 나타나 있다. 또한 해석에 사용되 는 하중조건은 Table 6에 제시하였다. Abaqus의 해석 결과와 $\mathrm{CDS}$ 프로그램의 결과와는 자긴 반경이나 원주 방향의 응력 결 과가 차이나지만 그 오차가 약 $5 \%$ 미만을 나타내며 비슷한 경향 성을 보인다는 것을 확인할 수 있다. 이로써 자긴 가공 후 실린 더에 내압이 작용하는 조건을 잘 모사할 수 있음을 확인하였다.

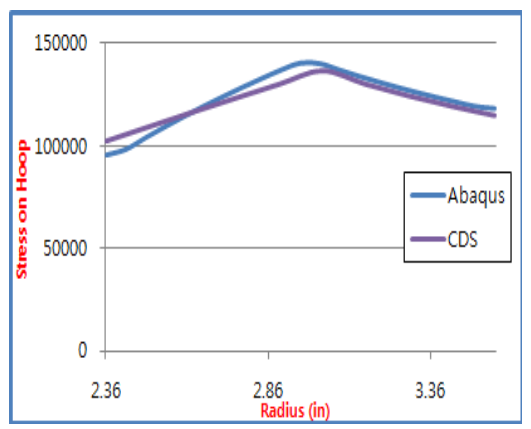

Fig. $1150 \%$ 자긴 가공 후 내압에 대한 원주방향 응력 값.

\begin{tabular}{|c|c|}
\hline Value & Property \\
\hline 자긴률 & $50 \%$ \\
\hline$P_{i}$ & 62,600 (psi) \\
\hline$P_{o}$ & 0 \\
\hline
\end{tabular}

\section{3 온도 효과를 고려한 자긴 가공 해석}

본 논문에서 강/복합재 이중구조 실린더는 강부만 자긴 가공 후 복합재를 감는 공정을 실시하여 제조한다고 가정한다. 위 과 정에서 복합재를 감는 공정에서 맨드럴의 낮은 온도에 의한 잔류 응력이 발생하게 되는데, 이를 이용하여 자긴 효과를 얻을 수 있 다는 점에서 무시할 수 없는 부분이다. 본 해석에서는 맨드럴과 강재의 온도차를 $81^{\circ}$ 로 맨드럴의 온도를 낮게 잡았으며, 강재의 열전달을 고려하였다. 온도 효과의 도입을 위한 검증과정에서 프 로그램은 Nastran을 사용하였으며, 해석을 위한 2D 설계 형상은 Fig. 12에 나타내었으며, 요소 수는 3164개로 설정하였다.

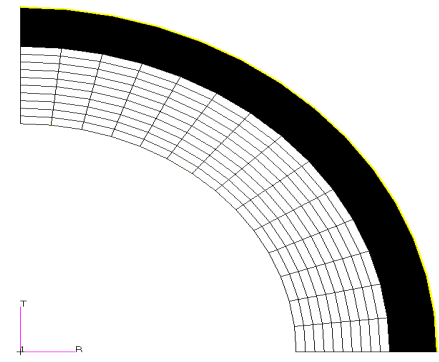

Fig. 12 유한요소 해석을 위한 Nastran 2D 설계 형상.

2D Nastran 해석에서 강부의 온도 효과를 고려한 강/복합 재 이중구조 실린더의 내압 작용 해석을 실시하여 $\mathrm{CDS}$ 프 로그램의 해석 결과의 원주 방향과 반경 방향 응력을 각각 비교하였다. 검증을 위해 비교한 그래프를 Fig. 13, 14에 나 타내었으며, 비교를 위한 해석 결과에 사용된 하중조건을 Table 7에 제시하였다. 두가지 모두 잘 일치하는 경향을 보 이고 있고 모델의 타당성을 검증할 수 있었다.

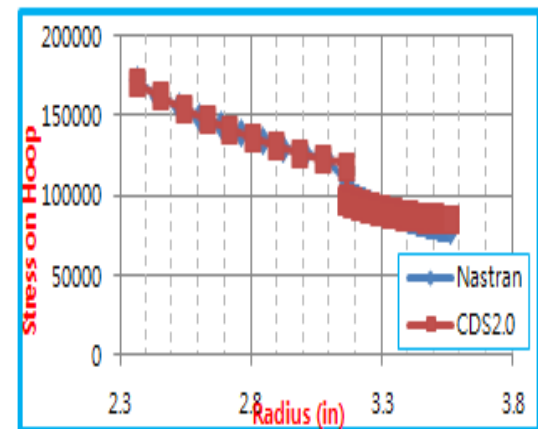

Fig. 13 2D Nastran vs CDS 프로그램 원주 방향 응력 비교. 


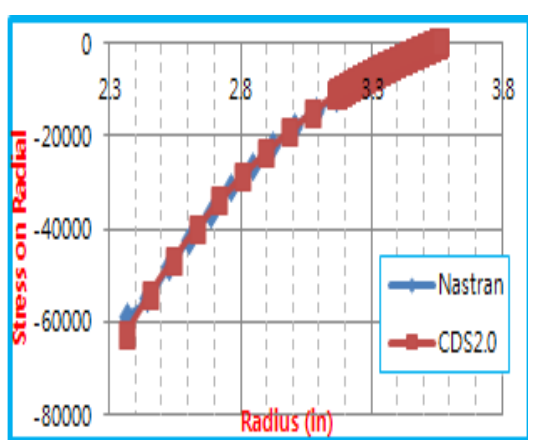

Fig. 14 2D Nastran vs CDS 프로그램 반경 방향 응력 비교.

Table 7 온도효과를 고려를 검증하기 위한 하중조건

\begin{tabular}{c|c}
\hline \hline Value & Property \\
\hline 자긴률 & $100 \%$ \\
$P_{i}$ & $62,600(\mathrm{psi})$ \\
$P_{o}$ & 0 \\
\hline \hline
\end{tabular}

다음으로는 온도차를 고려할 때와 고려하지 않을 때의 결 과를 Fig. 15에 비교하였다. 온도를 고려하면 강부에서는 응 력이 약간 감소하지만 복합재에서는 응력이 약간 높아짐을 알 수 있다. 이는 강부의 수축으로 인해 압축효과를 주지만 복합재 부분은 상온시 강재의 팽창으로 인해 인장응력이 가 해져 약 $2 \%$ (Table 8)의 응력상승이 있음을 알 수 있다. 또한 온도효과를 고려한 해석이 실제 현상에 더 가까운 결과 값을 나타낸다. 따라서 온도효과는 복합재의 응력상승에 영향을 미치므로 고려할 인자로 판단된다.

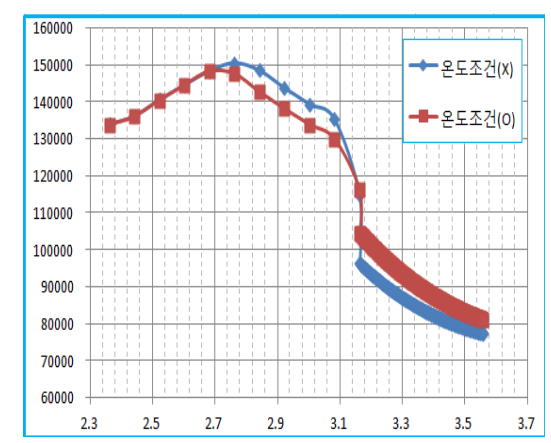

Fig. 15 자긴-온도 효과를 고려한 원주 방향 응력 비교.

Table 8 온도효과의 영향력에 대한 최대 응력 비교

\begin{tabular}{c|c}
\hline \hline Value & Property \\
\hline 온도고려(O) & $148,218(\mathrm{psi})$ \\
온도고려(X) & $150,529(\mathrm{psi})$ \\
응력 값의 차 & 약 $2 \%$ \\
\hline \hline
\end{tabular}

\section{3. 결 론}

본 연구에서는 상용 프로그램인 Nastran과ABAQUS, CDS 을 사용한 유한요소 해석을 통하여 강/복합재 이중구조 실린 더 설계를 위한 유한요소 해석을 수행하여 다음의 결론을 얻 을 수 있었다.

(1) 내압을 받는 경우만을 고려하여 세 가지 복합재료를 대상을 해석을 수행한 결과 대상 후보군 중에는 T300/5208 이 상대적으로 유리했다.

(2) 내압을 받는 경우 가장 유리한 적층각을 찾기 위해 안전계수와 Tsai-Wu 파괴지수의 개념으로 해석해본 결과 D 경우의 적층, 즉 각도를 점진적으로 줄여가며 적층하는 것이 급격한 응력분포의 변화가 없이 연속적인 분포를 이루고, 장 시간 사용시 문제점이 적을 것으로 판단된다. 그러나 가공의 측면에서는 다소 비용상승의 문제점도 있을 수 있다.

(3) 자긴 효과는 잔류응력을 만들어 응력을 감내하는 능 력을 키우기 위함인데 본 연구에서는 이를 적절히 모델링 하 여 해석을 수행하였으며, 내압과 자긴 효과를 모두 고려한 해석을 수행하여 결과의 타당성을 보였다.

(4) 가공 시 맨드럴의 온도가 낮은 점을 감안하여 온도를 고려하는 해석을 수행하였고, 내압과 자긴 효과와 온도를 모 두 고려했을 때 복합재 부분의 응력이 $2 \%$ 가량 상승하여 온 도를 고려해야할 필요성을 제시하였다.

이상의 결과들을 종합하여 본 연구에서는 강/복합재 이중 구조가 내압과 자긴 효과 그리고 온도효과를 고려할 수 있는 해석기법을 통해 설계 시 해석의 타당성을 검증하였다. 이러 한 결과는 향후 복합재료로 강화된 고압 실린더나 압력용기 등에 응용될 수 있을 것으로 생각된다.

\section{후 기}

본 연구는 부산대학교 자유학술과제연구(2년)지원과, 풍력 발전 고등 기술개발 및 인력양성사업 지원으로 수행된 것이 며, 지원에 대해 진심으로 감사드립니다.

\section{참고문헌}

1) Parker, A.P., “A Re-Autofrettage Procedure for Mitigation of Bauschinger Effect in Thick Cyliders," Journal of Pressure Vessel Technology, Vol. 126, No. 4, 2004, pp. 451-454.

2) Hojjati, M.H., and Hassani, A., "Theoretical and finite-element modeling of autofrettage process in strain-hardening thick-walled cylinders," International Journal of Pressure Vessels and Piping, Vol. 84, No. 5, 2007, pp. 310-319. 
3) Kim, J.H., Shim, W.S., Lee, Y.S., Cha, G.U., and Hong, S.K., "A Study on Residual Stress Analysis of Autofrettaged Thick-walled Cylinders," Journal of the Korean Society of Precision Engineering, Vol. 26, No. 12, 2009, pp. 110-116.

4) Park, J.H., Lee, Y.S., Kim, J.H., Cha, G.U., and Hong, S.K., "Machining Analysis of the Autofrettaged Compound Cylinder," The Korean Society of mechanical engineers A, Vol. 31, No. 7, 2007, pp. 800-807.

5) Lee, K.K., and Kim, W.D., "Behavior and Optimization of Cylinder Applied by Composite Tape Wrapping Method,” The Korean Society for Composite Materials, Vol. 24, No. 2, 2011, pp. 22-29.

6) Tabakov, P.Y., and Summers, E.B., "Lay-up optimization of multilayered anisotropic cylinders based on a 3-D elasticity solution,” Computers and Structures, Vol. 84,
No. 5-6, 2006, pp. 374-384.

7) Jacquemin, F., and Vautrin, A., “Analytical Calculatiion of the Transient Thermoelastic Stresses in Thick Walled Composite Pipes," Journal of Composite Materials, Vol. 38, No. 19, 2004, pp. 1773-1751.

8) Jones, R.M., Mechanics of Composite Materials, International student ed., McGraw-Hill Kogakusha, LTD., 1975.

9) Whitney, J.M., Structural Analysis of Laminated Anisotropic Plates, Technomic Pub. Co., 1987.

10) Lee, K.K., and Kim, W.D., "Thermo-structural analysis and design of 3D composite rocket nozzle," Proceeding of Spring Conference The Korean Society for Composite Materials, 2010, pp. 147-151.

11) Kim, C.Y., and Kim, W.D., "Analysis of Steel/composite Cylinder by GUI Program," The Korean Society for Composite Materials, Vol. 25, No. 4, 2012, pp. 126-132. 